\title{
Lantana camara: Phyto-constituents and Antimicrobial Activity Study
}

\section{Sunday O. Oladoye ${ }^{1}$, Victoria A. Falade ${ }^{*}$, Adewusi J. Adepoju ${ }^{1}$, Geshin J. Ibikunle $^{2^{*}}$}

${ }^{1}$ Department of Pure and Applied Chemistry, Ladoke Akintola University of Technology, Ogbomoso, P.M.B. 4000, Nigeria.

${ }^{2}$ Department of Science Laboratory Technology, Ladoke Akintola University of Technology, P.M.B. 4000. Ogbomoso, Nigeria

\author{
*Correspondence should be addressed to Victoria A. Falade and Ghesin J. Ibikunle: vafalade@lautech.edu.ng, \\ gj@lautech.edu.ng \\ Received 5th May 2021; Revised 21st June 2021; Accepted 5th July2021 \\ (C) 2021 Oladoye et al. Licensee Pan A frican Journal of Life Sciences an official publication of Faculty of Basic Medical Scienc- \\ es, Ladoke Akintola University of Technology, Ogbomoso. This is an Open Access article distributed under the terms of the \\ Creative commons Attribution License (https://creativecommons.org/licenses/BY/4.0), which permits unrestricted use, distribu- \\ tion, and reproduction in any medium, provided the original work is properly cited.
}

\begin{abstract}
Background: The development of resistance by pathogenic organisms has caused renewed interest in medicinal plants as alternative antimicrobial agents in treating diseases and infections. Lantana camara is an evergreen shrub commonly found in the tropical and sub-tropical regions, different parts of the plant have been used traditionally in the treatment of fever, diarrheal, scabies, cold, skin infections etc. This study therefore, seeks to investigate the phytochemical composition and potential of Lantana camara extracts as an alternative antimicrobial agents.

Methods: According to standard methods in this study, qualitative and quantitative phytochemical screening of Lantana camara leaves extracts was done. In vitro antimicrobial activity of the extract were evaluated against gram-positive and negative bacteria (Escherichia coli, Pseudomonas aeruginosa, Klebsiella oxytoca, Proteus vulgaris, Staphylococcus aureus, and Salmonella typhi) and fungal strains (Aspergillus flavus, Aspergillus niger, Aspegillus fumigatus, Fusarium poae, and Fusarium solani) using well-diffusion and mycelia inhibition method, respectively.

Results: Phytochemical screening of the extracts revealed saponins, phenols, tannins, flavonoids, steroids, cardiac glycosides, and alkaloids, with tannins $(70.454 \pm 0.002 \mathrm{mg} / \mathrm{g})$ found to be abundant in ethanolic extract. The extracts displayed moderate to high inhibitory activities on the tested strains with E.coli and A. flavus highly inhibited by the extracts.

Conclusion: The present study clearly showed that the crude extracts are rich in diverse phytochemicals and are potential sources of antimicrobial principles that could be used in the management of diseases and infections.
\end{abstract}

Keywords: Lantana camara, alternative antimicrobial agents, antibacterial activity, antifungal activity. 


\subsection{INTRODUCTION}

The use of plants in the treatment and management of diseases and infections dates back to history. The last few decades have witnessed a renewed interest in plants as alternative antimicrobial and therapeutic agents due to increasing microbial resistance to available antibiotics. These plant parts owe their therapeutic effects to different secondary metabolites with diverse mechanisms of action.

Lantana camara Linn commonly called wild or red sage, belongs to the family Verbenaceae. It is an evergreen notorious wild shrub that grows well in tropical and temperate regions [1]. It is a woody-smelling plant growing up to $1-3$ meters; the flowers are often in clusters and diverse colors ranging from red, violet, white, yellow, and pink, often cultivated as an ornament plant but have now become an invasive weed [2]. The leaves are usually green, opposite, simple and ovaloblong in shape with a length between $2-10 \mathrm{~cm}$ and width $2-6 \mathrm{~cm}$, the stems are woody and thorny while the roots are very strong [3].

Different parts of the plant have found application in folk medicine; the leaves are reportedly used to relieve toothache and stomachache, stimulate wound healing, and treat diarrheal, rheumatism, skin infection, ulcer, bronchitis, and biliary fever [4]. Essential oil from the plant is used to treat and manage tumors, leprosy, measles, tetanus, skin itches, chicken pox, cancer, asthma, ulcers, and high blood pressure [5]. Insecticidal, fumigant, and antiseptic activity of the plant have also been reported [6]. Antimicrobial, anti-inflammatory, antinociceptive, anti-mycobacterial, anticancer, antioxidant, anti-helminthic, and antiulcer activities of the plant have also been reported in the literature [7].

\subsection{METHODOLOGY}

\subsection{Preparation of the Plant Material}

L. camara leaves were collected in Ogbomoso Oyo state Nigeria in January 2020. The sample was identified by Professor A.T.J. Ogunkunle of the Department of Pure and Applied Biology, Ladoke Akintola University of Technology, Ogbomoso, Nigeria. The leaves were washed in distilled water (to remove dust, dirt, and other contaminants), air-dried, and pulverized using QBL20L40 QASA blender. The pulverized plant material $(1.40 \mathrm{~kg})$ was successively extracted with $\mathrm{n}$-hexane, ethyl acetate, and ethanol for one (1) week each, filtered, and the filtrate concentrated in vacuo. The resulting crude extracts were kept in airtight container till further analysis, and the percentage yield was calculated as follows:

$$
\% \text { yield }=\frac{\text { mass of plant extract }}{\text { mass of dried plant sample }} \times 100
$$

\subsection{Qualitative Phytochemical Evaluation}

Secondary metabolites present in n-hexane, ethyl acetate, and ethanolic extracts of Lantana camara leaves were evaluated according to the study by Harbourne [8]. Phytochemicals tested for include, Alkaloids (Wagner's Test), Flavonoids (Lead acetate Test), Saponins (Froth's Test), Glycosides (Liebermann's test), Tannins (Braymer's Test), Cardiac Glycosides (Keller Killiani Test), carbohydrate (Molisch's test), Steroids (Salkowaski's Test), Phenols (Ferric chloride), Coumarins (Reaction with $10 \% \mathrm{NaOH}$ ), Terpenoids (Salkowaski's test) and Anthraquinones (Borntrager's test). The presence or absence of the phytochemical was indicated by positive $(+)$ and negative $(-)$ signs, respectively.

\subsubsection{Alkaloids}

To $0.2 \mathrm{~g}$ of the plant extracts in a test tube was added 2 $\mathrm{ml}$ of Wagner's reagent (iodine dissolved in potassium iodide), the appearance of a yellow precipitate showed the presence of alkaloids.

\subsubsection{Flavonoids}

Exactly $1 \mathrm{ml}$ of $10 \%$ lead acetate was added to $0.2 \mathrm{~g}$ of Lantana camara leaf extracts, the development of a yellow precipitate is a preliminary test for the presence of flavonoids.

\subsubsection{Cardiac Glycosides}

Two drops of $\mathrm{FeCl}_{3}$ (ferric chloride solution) was added to $1 \mathrm{ml}$ of $5 \%$ glacial acetic acid, the resulting solution was added to $0.2 \mathrm{~g}$ of $L$. camara leaf extract, after which 3 drops of concentrated solution of teraoxosulphate (VI) acid $\left(\mathrm{H}_{2} \mathrm{SO}_{4}\right)$ was added, appearance of a brown ring is a positive indication for cardiac glycosides.

\subsubsection{Saponins}

Exactly $0.2 \mathrm{~g}$ each of the extracts was dissolved in $10 \mathrm{ml}$ of distilled water, shaken vigorously, and allowed to stand for 30 minutes. The appearance of a stable froth is a positive indication for saponins. 


\subsubsection{Glycosides}

To $2 \mathrm{ml}$ of chloroform was added $2 \mathrm{ml}$ of acetic acid. The resulting solution was added to $0.2 \mathrm{~g}$ of $L$. camara leaf extract. A green ring at the interface is a positive test for glycosides

\subsubsection{Tannins}

In this test, $0.2 \mathrm{~g}$ each of the extracts were dissolved in 3 $\mathrm{ml}$ of distilled water, after which 2 drops of $5 \% \mathrm{FeCl}_{3}$ solution was added, formation of a green precipitate suggests the presence of tannins.

\subsubsection{Carbohydrates}

$0.2 \mathrm{~g}$ of $L$. camara extract was dissolved in $5 \mathrm{ml}$ of distilled water and filtered. Three drops of $1 \%$ alcoholic alpha naphthol was added along the side of the test tube, after which $2 \mathrm{ml}$ concentrated tetraoxosulphate (VI) acid was added. The appearance of a violet ring at the interface indicated the presence of carbohydrates.

\subsubsection{Steroids}

$0.2 \mathrm{~g}$ of $L$. camara extract was added to $2 \mathrm{ml}$ of chloroform, after which of 3 drops of concentrated $\mathrm{H}_{2} \mathrm{SO}_{4}$ was added along the side of the test tube. The appearance of a reddish-brown colour at the interface was indicative of steroids.

\subsubsection{Phenols}

Phenolic content was determined by adding $0.2 \mathrm{~g}$ of the crude plant extract to $2 \mathrm{ml}$ of distilled water, followed by three (3) drops of $\mathrm{FeCl}_{3}$ solution. The appearance of an intense green colour showed the presence of the phenolic group

\subsubsection{Coumarin}

Exactly $1 \mathrm{ml}$ of $10 \%$ sodium hydroxide was added to 0.2 $\mathrm{g}$ each of the plant extracts. The appearance of yellow colour is indicative of the presence of Coumarin .

\subsubsection{Terpenoids}

A combination of $2 \mathrm{ml}$ of acetic anhydride and $3 \mathrm{ml}$ of concentrated tetraoxosulphate (VI) acid was added to 0.2 $\mathrm{g}$ of the plant extract in a test tube. The appearance of a deep red colour is a positive test for terpenoids.

\subsubsection{Anthraquinone}

To $0.2 \mathrm{~g}$ of $L$. camara extract was added $2 \mathrm{ml}$ of dilute $\mathrm{H}_{2} \mathrm{SO}_{4}$, the resulting solution was filtered, washed with 2 $\mathrm{ml}$ of chloroform, and shaken vigorously, after which 2 $\mathrm{ml}$ of ammonia solution was added. A pink colouration suggests the presence of anthraquinone

\subsection{Quantitative Phytochemical Evaluation}

\subsubsection{Alkaloids}

The quantity of alkaloids present in L. camara extracts was evaluated using a previously established method [8]. Exactly $0.5 \mathrm{~g}$ of the crude extract was extracted with a mixture of ethanol and ethanoic acid (9:1) for $4 \mathrm{~h}$. The mixture was filtered with Whatman No. 42 filter paper, and the volume of the filtrate was reduced to $30 \mathrm{ml}$ over a hot water bath. The concentrated filtrate was then precipitated with concentrated aqueous ammonia. The precipitate was filtered with Whatman No. 42 filter paper and dried till constant weight in an oven. Total alkaloid content was calculated as a percentage.

\subsubsection{Flavonoids}

\section{Total alkaloid content $=$ weight of precipitate $\mathrm{X} 100$}

Aluminum chloride colorimetric assay was used for flavonoid quantification. Thus, $13 \mathrm{mg}$ of each $L$. camara extract was dissolved in $26 \mathrm{ml}$ of methanol and filtered, $4 \mathrm{ml}$ of distilled water and $0.30 \mathrm{ml}$ of $5 \%$ sodium nitrite were added to the filtrate and shaken vigorously for $5 \mathrm{~min}$. Then, $0.3 \mathrm{ml}$ of $10 \%$ aluminum chloride and $2 \mathrm{ml}$ of $1 \mathrm{M}$ sodium hydroxide were added, and the resulting flavonoid-aluminum complex was diluted with $3 \mathrm{ml}$ of distilled water. Graded concentrations of Quercetin (20, 40, 60, 80, and $100 \mu \mathrm{g} /$ $\mathrm{ml}$ ) were used as standard, and absorbance taken at 510 $\mathrm{nm}$. Total flavonoid concentration present in L. cama$r a$ extract was expressed as milligram of Quercetin equivalent per gram of the extract [9].

\subsubsection{Saponins}

Total The total saponin content of L. camara extracts was evaluated accordingly [10]. Exactly $0.5 \mathrm{~g}$ each of the extracts were extracted with $100 \mathrm{~cm}^{3}$ of $90 \%$ ethanol, the resulting extract was filtered, and volume of the filtrate was reduced to $40 \mathrm{ml}$ over a hot water bath. The concentrated filtrate was further extracted with $10 \mathrm{ml}$ of diethyl ether (to remove fats) in a separating funnel. The ether layer was discarded while the aqueous layer was hydrolyzed with $60 \mathrm{ml}$ of n-butanol to liberate any aglycone present and washed with $10 \mathrm{ml}$ of $5 \%$ aqueous sodium chloride. The resulting solution was evaporated to constant weight in a beaker, and percentage saponins content was calculated.

Total saponin content $=\frac{\text { weight of evaporated filterate }}{\text { weight of extract used }} \times 100$ 


\subsubsection{Tannins}

Total amount of tannins present in L. camara leave extracts was determined using the Folin - Ciocalteus method as described [11]. Exactly $13 \mathrm{mg}$ each of the crude extracts were extracted with $26 \mathrm{ml}$ of methanol and filtered through Whatman No. 42 filter paper. $0.1 \mathrm{ml}$ of the filtrate was diluted with $7.5 \mathrm{ml}$ of distilled water, after which $0.5 \mathrm{ml}$ of Folin-Ciocalteus reagent (mixture of phosphomolybdate and phosphotungstate) and $1 \mathrm{ml}$ of 35 $\% \mathrm{Na}_{2} \mathrm{CO}_{3}$ were added. The resulting mixture was vigorously shaken and allowed to stand for 30 minutes to form bluish-green colour. Gallic acid solution (20, 40, 60, 80, and $100 \mu \mathrm{g} / \mathrm{ml}$ ) was used as a standard for comparison while absorbance was read at $725 \mathrm{~nm}$. The total amount of tannin present in the extract was calculated as a milligram of Gallic acid equivalent per gram of the extract.

\subsubsection{Phenol}

The folin-Ciocalteus method was used in the quantitative determination of phenol content of $L$. camara crude extract. Thus, $13 \mathrm{mg}$ of the crude extracts were dissolved in methanol and filtered through Whatman No. 42 filter paper. $1 \mathrm{ml}$ of Folin-Ciocalteus reagent (mixture of phosphomolybdate and phosphotungstate) and $9 \mathrm{ml}$ of distilled water were added to $1 \mathrm{ml}$ of the filtrate and the mixture was allowed to stand for $5 \mathrm{~min}$. $10 \mathrm{ml}$ of $7 \%$ sodium carbonate $\left(\mathrm{Na}_{2} \mathrm{CO}_{3}\right)$ was further added to enhance the oxidation of phenol in the extract by Folin-Ciocalteus reagent. The graded concentration of Gallic acid (20, 40, 60, 80, and $100 \mu \mathrm{g} / \mathrm{ml}$ ) were prepared and used as a standard while absorbance was read at $550 \mathrm{~nm}$. Total phenol content was calculated and presented as milligram $(\mathrm{mg})$ of Gallic acid equivalent per gram (GAE/gm) of the extract [11].

\subsection{Antimicrobial Susceptibility Test}

\subsubsection{Test Organism Collection}

The organisms used in this study are clinical isolates obtained from Bowen University Teaching Hospital, Ogbomoso, Oyo State, Nigeria. The bacteria isolates are Escherichia coli, Klebsiella oxytoca, Pseudomonas aeruginosa, Proteus vulgaris, Staphylococcus aureus, and Salmonella typhii while the fungi used are Aspergillus flavus, Aspergillus fumigatus, Aspergillus niger, Fusarium solani and Fusarium poae.

\subsection{Antibacterial Susceptibility}

Agar well diffusion method was used in evaluating the susceptibility of the bacteria to n-hexane, ethyl acetate, and ethanol extracts of L. camara [12]. Each test bacteria
(Proteus vulgaris, Klebsiella oxytoca, Escherichia coli, Staphylococcus aureus, Pseudomonas aeruginosa, and Salmonella typhii) were sub-cultured in sterilized peptone water and incubated for $18 \mathrm{~h}$ at $37^{\circ} \mathrm{C}$. The inoculum was applied on Mueller-Hinton Agar (Lab M Ltd.) plates using a sterile swab stick, after which cork borer of diameter $7 \mathrm{~mm}$ was used to create five (5) wells to which $100 \mu 1$ of different concentrations of the crude extracts were added. An additional well was also created at the center of the plate to which DMSO (serving as negative control) was added, while a standard antibiotic disk (Abtek Biologicals Ltd., UK) containing the following antibiotics were used for gram-positive bacteria; ceftriaxone $30 \mu \mathrm{g}$, tetracycline $30 \mu \mathrm{g}$, augmentin 30, gentamycin $10 \mu \mathrm{g}$, ofloxacin $5 \mu \mathrm{g}$, amoxicillin $25 \mu \mathrm{g}$, ciprofloxacin $5 \mu \mathrm{g}$, and pefloxacin $10 \mu \mathrm{g}$. For gram-negative bacteria, the following antibiotics were used; ciprofloxacin $5 \mu \mathrm{g}$, amoxicillin $25 \mu \mathrm{g}$, pefloxacin $10 \mu \mathrm{g}$, ofloxacin $5 \mu \mathrm{g}$, chloramphenicol $30 \mu \mathrm{g}$, streptomycin $30 \mu \mathrm{g}$, cephalothin $30 \mu \mathrm{g}$, gentamycin $10 \mu \mathrm{g}$, cotrimoxazole $25 \mu \mathrm{g}$, and erythromycin $5 \mu \mathrm{g}$. The plates were incubated at $37^{\circ} \mathrm{C}$ for 24 hours, after which the antibacterial activity of the extract and the standards were recorded as visible zones in diameter.

\subsection{Antifungal activity}

Mycelia inhibition method was used in the evaluation of the antifungal potential of $L$. camara extracts as previously described [13]. Exactly $2 \mathrm{ml}$ of $50 \mathrm{mg} / \mathrm{ml}$ of the crude extract was mixed with Potato Dextrose Agar (PDA), poured into a sterile Petri dish, and allowed to cool. Then, $6 \mathrm{~mm}$ agar plugs of fungi (A spergillus niger, A spergillus fumigatus, Aspergillus flavus, Fusarium solani and Fusarium poae) were placed at the center of the plate and incubated at $28{ }^{\circ} \mathrm{C}$ for $72 \mathrm{~h}$. The fungal plugs inoculated on PDA plates without incorporation of $L$. camara served as control. Radial growth of the fungi were measured in diameters $(\mathrm{mm})$ and was used to calculate percentage growth inhibitions:

$$
\% \text { Growth Inhibition }=\frac{\text { Dcontrol }- \text { Dtest }}{\text { Dcontrol }} \times 100
$$

$\mathrm{D}$ : is the fungal growth in diameter $(\mathrm{mm})$ on PDA plates.

\subsection{RESULTS AND DISCUSSION}

\subsection{Extraction wth Different Solvent}

Solvent extraction of secondary metabolites from plant parts is one of the most widely used approach in 
therapeutic and pharmacological investigation of plant materials; it involves diffusion/penetration of the solvent into the solid plant material and compounds with higher affinity for each solvent are solubilized. Solvent extraction yields are often influenced by polarities of solvents, extraction method, duration of extraction, temperature of extraction among others. n-hexane, ethyl acetate and ethanol were used to successively extract secondary metabolites from $L$. camara leaves, the percentage yield of the extract are $4.30 \%, 4.67 \%$ and $4.14 \%$ for $n$-hexane, ethyl acetate and ethanol respectively. These results clearly showed that more of the secondary metabolites were solubilized in ethyl acetate.

\subsection{Qualitative and Quantitative Screening}

Medicinal and therapeutic potential of plants have been associated with presence of phytochemicals, which have been found to have wide range applications in the treatment and management of diseases and infections. Phytochemical components of plants are influenced by factors such as extraction solvent, climate, geographical location, time of harvest, physiological age of plant among others. Preliminary qualitative phytochemical screening results provide essential information on the presence or absence of secondary metabolites which in turn helps in drug discovery from plants.

The results obtained from the preliminary phytochemical investigation of $L$. camara leaves are summarized in Table 1, data from the table showed that alkaloids, flavonoids, tannins, phenols, steroids and cardiac glycosides were present in the three extracts (n-hexane, ethyl acetate and ethanol), terpenoids, carbohydrates and coumarins were found in both ethyl acetate and ethanol extracts while glycosides was identified only in ethanol extract. This investigation however, did not detect the presence of anthraquinones in the three extracts. The presence of alkaloids, saponins, phytosterols, glycosides, tannins, terpenoids, steriods and flavonoids had previously been reported in L. camara [14,15].

Similarly, Table 2 provides information on the quantitative phytochemical composition of $L$. camara leaf extracts, which clearly showed that flavonoids, tannins and phenols contents of the leaf increased with increasing polarity of the solvents. It is also important to note that tannin content of L. camara leaf are far higher than those of other phytochemicals detected in this study, with the
Table 1. Qualitative phytochemical screening of L. cama$r a$ extracts

\begin{tabular}{|c|c|c|c|c|}
\hline & Parameters & Hexane & $\begin{array}{l}\text { Ethyl } \\
\text { acetate }\end{array}$ & $\overline{\text { Ethanol }}$ \\
\hline 1 & Saponin (Froth's Test) & + & + & + \\
\hline 2 & Alkaloid (Wagner's & + & + & + \\
\hline 3 & $\begin{array}{l}\text { Test) } \\
\text { Flavonoid (Lead acetate }\end{array}$ & + & + & + \\
\hline 4 & $\begin{array}{l}\text { Test) } \\
\text { Tannin (Braymer's Test) }\end{array}$ & + & + & + \\
\hline 5 & Phenol (Ferric chloride) & + & + & + \\
\hline 6 & Steroid (Salkowaski's & + & + & + \\
\hline 7 & $\begin{array}{l}\text { Test) } \\
\text { Cardiac Glycosides } \\
\text { (Keller Killiani test) }\end{array}$ & + & + & + \\
\hline 8 & $\begin{array}{l}\text { Terpenoid (Salkowaski’s } \\
\text { test) }\end{array}$ & - & + & + \\
\hline 9 & $\begin{array}{l}\text { Carbohydrate (Molisch's } \\
\text { test ) }\end{array}$ & - & + & + \\
\hline 10 & Coumarin (Reaction with & - & + & + \\
\hline 11 & $\begin{array}{l}10 \% \mathrm{NaOH}) \\
\text { Glycosides }\end{array}$ & - & - & + \\
\hline 12 & $\begin{array}{l}\text { (Liebermann's test) } \\
\text { Anthraquinone } \\
\text { (Borntrager's test) }\end{array}$ & - & - & - \\
\hline
\end{tabular}

highest amount of tannin found in ethanol extract $(70.454 \pm 0.002 \mathrm{mg} / \mathrm{g})$. A closer inspection of the table revealed that the leaves are especially rich in phenolic compounds (flavonoids $((24.500 \pm 0.012 \mathrm{mg} / \mathrm{g}))$, tannins $(70.454 \pm 0.002 \mathrm{mg} / \mathrm{g})$ and phenol $(10.733 \pm 0.014 \mathrm{mg} / \mathrm{g})$.

Phenolics are natural bioactive compound having one or more aromatic groups to which one or more hydroxyl groups are attached, it comprises of the simple phenolic acid to the more complex polyphenols (e.g tannins and flavonoids)[16].

Table 2. Quantitative Screening of L. camara Extracts

\begin{tabular}{|l|c|c|l|}
\hline $\begin{array}{l}\text { Parame- } \\
\text { ters }\end{array}$ & Hexane & Ethyl acetate & Ethanol \\
\hline $\begin{array}{l}\text { Saponins } \\
(\%)\end{array}$ & $1.500 \pm 0.006$ & $5.500 \pm 0.019$ & $3.500 \pm 0.033$ \\
\hline $\begin{array}{l}\text { Alkaloids } \\
(\%)\end{array}$ & $0.500 \pm 0.002$ & $6.600 \pm 0.003$ & $0.700 \pm 0.003$ \\
\hline $\begin{array}{l}\text { Flavonoids } \\
\text { (mg/g) }\end{array}$ & $11.325 \pm 0.051$ & $17.806 \pm 0.045$ & $24.500 \pm 0.012$ \\
\hline $\begin{array}{l}\text { Tannins } \\
(\mathrm{mg} / \mathrm{g})\end{array}$ & $39.860 \pm 0.006$ & $45.687 \pm 0.002$ & $70.454 \pm 0.002$ \\
\hline $\begin{array}{l}\text { Phenols } \\
(\mathrm{mg} / \mathrm{g})\end{array}$ & $1.225 \pm 0.003$ & $1.767 \pm 0.009$ & $10.733 \pm 0.014$ \\
\hline
\end{tabular}


There is a large volume of published studies describing antioxidant potential of phenolics, and in fact, the relationship between consumption of fruits/vegetables and reduced risk of cardiovascular diseases has been linked to their phenolic content [17].

This activity have been attributed to their ability to donate hydrogen atoms, number and position of hydroxyl groups on the aromatic ring, and nature of substitution on the aromatic ring [18]. These secondary plant metabolites serve as free radical scavengers, singlet oxygen quenchers, and transition metal chelators, enhancing their antioxidant properties [16]. Anti-inflammatory, antiviral, antibacterial, anti-diabetic, anti-carcinogenic, antitumor, and hepatoprotective abilities of tannins have been reported in the literature [19]. Similarly, flavonoids have been found to possess anti-mutagenic, anti-inflammatory, antiviral anticancer, hepato-protective, anti-cholinesterase, antioxidant and cardio-protective properties [20].

An appreciable amount of saponins and alkaloid (5.500 \pm 0.019 and $6.600 \pm 0.003$ respectively) were also found in the ethyl-acetate extract of L. camara. Saponins are phytochemicals of great nutritional and therapeutic value as they possess the ability to lower blood pressure and cholesterol, protect liver cells, and are important adjuvant in vaccine preparations [21]. They are also good antiinflammatory, antioxidant, antimicrobial, anti-mutagenic anticancer, immune-modulatory, neuro-protective, and anticoagulant agents [22]. Alkaloids, on the other hand, are active antimicrobial, analgesic, anti-cholinesterase, and anti-inflammatory agents. They have also been proven to be potent anticancer and antitumor agents. These result findings suggest that phytochemicals present in $L$. camara in varying amounts and working synergistically with a different and novel mechanism of actions may be responsible for the reported use in folk medicine as well as pharmacological activities. Consumption of these phyto -rich plants is of great benefit in human health and is probable sources of bioactive compounds in managing infectious diseases.

\subsection{Antibacterial Susceptibility}

Table 3 represents the results obtained for investigating the susceptibility of the tested bacterial strains to L. cama$r a$ leaf extracts. The extracts displayed moderate to high inhibitory activities on all the tested bacterial, and susceptibility increases with increasing concentration of the extracts. The study also found that the bacterial were more susceptible to ethanolic extract compared to other extracts used in the study, with the highest antimicrobial activity recorded against the growth of $E$. coli at a concentration of $150 \mathrm{mg} / \mathrm{ml}(25.50 \pm 0.55 \mathrm{~mm})$. The observed high antibacterial effect of the ethanolic extract could be attributed to the presence of different classes of phytochemicals in the extract, which works synergistically as revealed in Table 1. Also, the high flavonoid, tannins, and phenol contents of the ethanolic extract, as shown in Table 2, could be responsible for this observation. It is important to note that $\mathrm{n}$-hexane $(21.83 \pm 0.73 \mathrm{~mm}$ at $150 \mathrm{mg} / \mathrm{ml})$ and ethanolic extract $(22.50 \pm 0.41 \mathrm{~mm}$ at $150 \mathrm{mg} / \mathrm{ml})$ were shown to be better antibacterial agents against $S$. aureus compared to ciprofloxacin $(19.50 \mathrm{~mm})$ and ofloxacin $(15.50 \mathrm{~mm})$ used as standard antibiotic in this study. Although the antibacterial activity of $L$. camara extracts was lower compared to those of standards antibiotics in the current study (except for $S$. aureus), the extracts could be said to have an appreciable inhibitory effect on all the tested organisms as shown in Plate 1. Hence, they are promising alternative antibacterial agents which could be sourced in the drug discovery process. This result compares favourably with the results of Dubey and Padhy which showed that $L$. camara extract had high inhibitory activity on $S$. aureus, $P$. vulgaris and $P$. aeruginosa [15], and that of Barretto and co-workers, which also established the inhibitory activity of $L$. camara extract on $E$. coli, $P$. vulgaris, $S$. aureus and $P$. aeruginosa [23].

$S$. aureus is an opportunist commensal bacteria found in humans. It is a leading cause of community-associated skin and soft tissue bacteremia [24]. K. oxytoca is also an opportunist healthcare-associated bacteria primarily found in intensive care and immune-compromised patients as well as surfaces in hospital environments [25]. They are usually found in the intestinal and respiratory tracts and are the leading cause of urinary tract infections, bronchopneumonia, wound infection [26]. P. aeruginosa, on the other hand, are also opportunistic bacteria in immunecompromised individuals. They are causative organisms of chronic and acute lung infections, unitary tract, and gastrointestinal tract infections. The organism has also been found to pose intrinsic resistance to antibiotics; hence, its infections are often difficult to treat [27]. S. typhi is found in the bloodstream, liver, spleens, and small intestine of an infected individual. It causes typhoid fever common in developing countries where poor sanitation and poor hygiene practices prevail [28]. E. coli is a com- 
Table 3. Antibacterial susceptibility test for L. camara extracts

\begin{tabular}{|c|c|c|c|c|c|c|}
\hline Organisms & Conc. $(\mathrm{mg} / \mathrm{ml})$ & $\begin{array}{l}\text { n-Hexane } \\
(\mathrm{mm})\end{array}$ & $\begin{array}{l}\text { Ethyl acetate } \\
(\mathrm{mm})\end{array}$ & Ethanol (mm) & $\overline{\text { DMSO }}$ & Standard (mm) \\
\hline \multirow[t]{5}{*}{ S. aureus } & 50 & $15.83 \pm 0.62$ & $15.00 \pm 0.81$ & $18.17 \pm 0.65$ & - & CPX: 19.50 \\
\hline & 75 & $17.50 \pm 0.08$ & $16.17 \pm 0.10$ & $19.00 \pm 0.41$ & - & OFL: 15.50 \\
\hline & 100 & $17.50 \pm 0.82$ & $17.33 \pm 0.78$ & $19.50 \pm 0.69$ & - & \\
\hline & 125 & $18.17 \pm 0.47$ & $17.53 \pm 0.13$ & $19.67 \pm 0.62$ & - & \\
\hline & 150 & $21.83 \pm 0.73$ & $18.00 \pm 0.87$ & $22.50 \pm 0.41$ & - & \\
\hline \multirow[t]{5}{*}{ P. vulgaris } & 50 & $15.33 \pm 0.01$ & $13.33 \pm 0.94$ & $14.17 \pm 0.36$ & - & TET: 26.50 \\
\hline & 75 & $17.00 \pm 0.41$ & $14.00 \pm 0.47$ & $14.83 \pm 0.85$ & - & \\
\hline & 100 & $17.17 \pm 0.62$ & $13.50 \pm 0.27$ & $15.17 \pm 0.72$ & - & \\
\hline & 125 & $17.17 \pm 0.31$ & $18.17 \pm 0.06$ & $16.33 \pm 0.65$ & - & \\
\hline & 150 & $17.43 \pm 0.03$ & $18.24 \pm 0.49$ & $18.33 \pm 0.47$ & - & \\
\hline \multirow[t]{5}{*}{ K. oxytoca } & 50 & $12.33 \pm 0.24$ & $12.33 \pm 0.10$ & $16.50 \pm 0.63$ & - & OFL: 30.50 \\
\hline & 75 & $14.33 \pm 0.18$ & $13.33 \pm 0.50$ & $17.33 \pm 0.31$ & - & PFX: 30.00 \\
\hline & 100 & $14.67 \pm 0.11$ & $13.67 \pm 0.78$ & $17.33 \pm 0.24$ & - & CPX:28.50 \\
\hline & 125 & $17.50 \pm 0.41$ & $15.33 \pm 0.47$ & $18.00 \pm 0.47$ & - & TET:27.50 \\
\hline & 150 & $18.33 \pm 0.85$ & $17.50 \pm 0.78$ & $22.00 \pm 0.08$ & - & \\
\hline \multirow[t]{5}{*}{ E. coli } & 50 & $7.83 \pm 0.47$ & $7.83 \pm 0.47$ & $18.33 \pm 0.03$ & - & TET:31.00 \\
\hline & 75 & $8.00 \pm 0.82$ & $11.50 \pm 0.48$ & $19.86 \pm 0.24$ & - & CPX:28.00 \\
\hline & 100 & $8.83 \pm 0.85$ & $12.50 \pm 0.86$ & $20.67 \pm 0.03$ & - & PFX:28.00 \\
\hline & 125 & $8.83 \pm 0.24$ & $14.50 \pm 0.41$ & $22.33 \pm 0.89$ & - & \\
\hline & 150 & $9.50 \pm 0.71$ & $15.17 \pm 0.65$ & $25.50 \pm 0.55$ & - & \\
\hline \multirow[t]{5}{*}{ S. typhii } & 50 & $11.50 \pm 0.47$ & $10.50 \pm 0.23$ & $16.17 \pm 0.18$ & - & CRO:30.00 \\
\hline & 75 & $11.83 \pm 0.65$ & $11.50 \pm 0.78$ & $16.67 \pm 0.85$ & - & \\
\hline & 100 & $11.83 \pm 0.85$ & $11.67 \pm 0.03$ & $17.33 \pm 0.24$ & - & \\
\hline & 125 & $13.33 \pm 0.31$ & $13.67 \pm 0.65$ & $18.33 \pm 0.65$ & - & \\
\hline & 150 & $14.00 \pm 0.82$ & $16.67 \pm 0.03$ & $18.67 \pm 0.47$ & - & \\
\hline \multirow{5}{*}{ P. aeruginosa } & 50 & $11.23 \pm 0.24$ & $8.83 \pm 0.62$ & $17.00 \pm 0.78$ & - & CRO:25.50 \\
\hline & 75 & $11.33 \pm 0.24$ & $8.83 \pm 0.24$ & $17.33 \pm 0.25$ & - & AUG:25.50 \\
\hline & 100 & $13.83 \pm 0.03$ & $10.33 \pm 0.84$ & $19.83 \pm 0.23$ & - & GEN:22.50 \\
\hline & 125 & $13.67 \pm 0.62$ & $11.50 \pm 0.68$ & $20.00 \pm 0.68$ & - & \\
\hline & 150 & $14.33 \pm 0.85$ & $13.33 \pm 0.25$ & $21.00 \pm 0.09$ & - & \\
\hline
\end{tabular}

AUG $=$ augmentin, OFL $=$ ofloxacin, $\mathbf{C R O}=$ ceftriaxone, GEN $=$ gentamycin, $\mathbf{C P X}=$ ciprofloxacin, $\mathbf{P E F}=$ pefloxacin and $\mathbf{T E T}=$ tetracycline. * Each of the values are means of 3 determinations

mon pathogen of the gastrointestinal tracts of humans and animals. It is responsible for a broad spectrum of diseases, including unitary tract infections (UTIs), diarrheal, and food poisoning [29]. Proteus vulgaris is also opportunist bacteria, it cause UTIs, infections of the bloodstream and digestive tracts, respiratory tract infections, skin infection, and resistance to antibiotics. Hence, infections caused by them are difficult to treat [30]. Evidence from the susceptibility of the tested bacteria strains to $L$. camara extracts suggests its potential in the treatment of diseases and infections caused by them.

\subsection{Antifungal Activity Result of $L$. camara Extracts}

The susceptibility of the tested fungi strains are presented in Table 4. The extracts displayed moderate to high antifungal activity on all the tested fungal strains. An increase in antifungal activity of the extracts as the polarity of solvents increases, was observed against $A$. fla$v u s$ and $F$. poae, which might probably be due to the presence of diverse phytochemical classes, coupled with increased quantities of tannins, flavonoids and phenols in the ethanolic extract as earlier shown in Table 2. Notably, the highest antifungal activity study was recorded against the growth of $A$. flavus (88.20\%). Similarly, $A$. niger $(83.78 \%$ ) and $F$. solanis $(84.47 \%)$ were more susceptible to ethyl acetate extract than other extraction solvents. These findings could be attributed to the ethyl acetate extract's high saponins and alkaloids contents as shown in Table 2. The extracts also displayed good inhibitory activities on the growth of A. fumigatus, it is however not clear why $F$. solani was resistant to the ethanolic extract.

Aspergillus fumigatus, A. flavus, and A. niger are members of the Aspergillus genus. The genus is known to reproduce asexually and consists of filamentous fungi known to be agents of opportunistic infections in immune-compromised individuals [31]. Grains such as maize, millet, guinea corn, onions, melon, and other 
Table 4. Antifungal activity of $L$. cam ara

\begin{tabular}{|c|c|c|c|c|c|c|c|}
\hline Organism & n-Hexane & & Ethyl ace & & Ethanol & & Control \\
\hline & $\mathrm{FG}(\mathrm{mm})$ & $\% \mathrm{GI}$ & FG (mm) & $\% \mathrm{GI}$ & $\overline{F G ~(m m) ~}$ & $\% \mathrm{GI}$ & $\mathrm{FG}(\mathrm{mm})$ \\
\hline A. flavus & 9.50 & 86.81 & 9.00 & 87.50 & 8.50 & 88.20 & 72.00 \\
\hline A. niger & 15.00 & 72.97 & 9.00 & 83.78 & 11.00 & 80.18 & 55.50 \\
\hline A. fumigatus & 8.00 & 86.67 & 10.00 & 83.33 & 7.50 & 87.50 & 60.00 \\
\hline F. solani & 9.00 & 82.52 & 8.00 & 84.47 & 26.50 & 48.54 & 51.50 \\
\hline F. poae & 9.50 & 79.79 & 9.00 & 80.85 & 8.50 & 81.92 & 47.00 \\
\hline
\end{tabular}

*FG = fungal growth, \% GI = \% growth inhibition

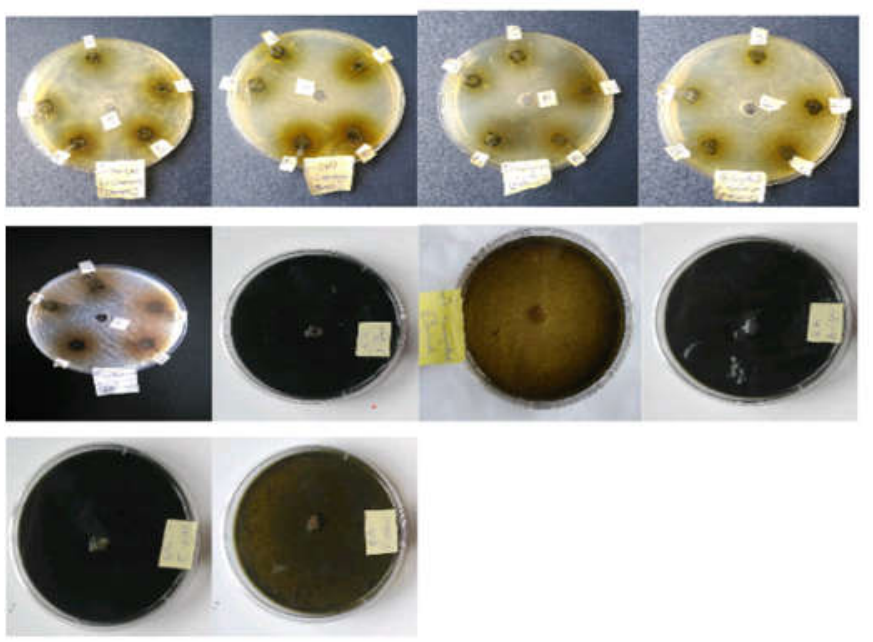

Plate 1. Plate Showing Antimicrobial Activities of $L$. $c a$ mara extracts.

foodstuff have been prone to Aspergillus and Fusarium proliferation, leading to their deterioration. Aspergillus spp and Fusarium spp growth on such food items results in the production of mycotoxins. These mycotoxins are stable to heat processing and treatment with chemicals. Hence they are often difficult to remove once contaminated with food [32]. Serious health problems including stunted growth, immune system suppression, cancer, and loss of lives have been associated with mycotoxins ingestion. It is apparent from this study that L. camara displayed good antifungal properties and could be employed as an alternative antibacterial agent in the treatment of infection caused by the pathogenic strains.

Phytochemical screening of the leaf extracts revealed that the plant contains diverse phytochemicals of which tannins, phenols, and flavonoids are abundant. The plant extract also displayed good antibacterial and antifungal properties on the tested pathogenic strains. These combinations of findings provide some support for the conceptual premises that phytochemicals present in plants are responsible for their various pharmacological activities and that L. camara is a potential source of alternative antimicrobial agents, especially in the treatment of diseases and infections caused by the tested pathogenic strains.

\section{Acknowledgement}

Technical Assistance rendered by Mr. S.B. Ogunsona and Mr. M.P. Obitokun is duly acknowledged

\section{Conflicts of Interest}

The Authors declares that there is no conflict of interest.

\section{Authors' Contribution}

SOO conceived and designed the study, contributed to data collection and data analysis tools. VAF, AJA and GJI contributed to data analysis tools, data analysis and manuscript writing. All authors approved the final copy of the manuscript.

\section{References}

1. Liu S, Ali S, Yang R, Tao J, Ren B. A newly discovered Cd-hyperaccumulator Lantana camara L. J Hazard Mater 2019; 371: 233-42. Available from: https:// doi.org/10.1016/j.jhazmat.2019.03.016

2. Ghisalberti EL. Lantana camara L. (Verbenaceae). Fitoterapia. 2000; $71: 467-86$.

3. Girish K. Antimicrobial activities of Lantana camara Linn. Asian J Pharm Clin Res. 2017; 10: 57-67.

4. Sousa EO, Miranda CMBA, Nobre CB, Boligon AA, 
Athayde ML, Costa JGM. Phytochemical analysis and antioxidant activities of Lantana camara and lantana montevidensis extracts. Ind Crops Prod. 2015; 70: 7-15. Available from: http://dx.doi.org/10.1016/ j.indcrop.2015.03.010

5. Seth R, Mohan M, Singh P, Haider SZ, Gupta S, Bajpai I, et al. Chemical composition and antibacterial properties of the essential oil and extracts of Lantana camara Linn. from Uttarakhand (India). Asian Pac J Trop Biomed 2012; 2: S1407-11. Available from: http:// dx.doi.org/10.1016/S2221-1691(12)60426-2

6. Rajashekar Y, Ravindra K V., Bakthavatsalam N. Leaves of Lantana camara Linn. (Verbenaceae) as a potential insecticide for the management of three species of stored grain insect pests. J Food Sci Technol. 2014; 51: 3494-9.

7. Hiremath KY, Jagadeesh N, Belur S, Kulkarni SS, Inamdar SR. A lectin with anti-microbial and anti proliferative activities from Lantana camara, a medicinal plant. Protein Expr Purif. 2020; 170: 105574. Available from: https:// doi.org/10.1016/j.pep.2020.105574

8. Harborne JB. Phytochemical Methods. Phytochem. Methods. Chapman and Hall Ltd. 1998 p. 1- 278.

9. Mallaiah P, Sudhakara G, Srinivasulu N, Sasi Bhusana Rao B, Vijayabharathi G, Saralakumari D. Assessment of in vitro antioxidant potential and quantification of total phenols and flavonoids of aqueous extract of Phyllanthus amarus. Int J Pharm Pharm Sci. 2015; 7: 439-45.

10. Obadoni BO, Ochuko PO. Phytochemical Studies And Comparative Efficacy Of The Crude Extracts Of Some Haemostatic Plants In Edo And Delta States Of Nigeria. Glob J Pure Appl Sci. 2002; 8: 203-8.

11. Tambe VD, Bhambar RS. Estimation of Total Phenol, Tannin, Alkaloid and Flavonoid in Hibiscus Tilaceus Linn. Wood extracts. Res Rev J Pharmacogn Phytochem. 2014; 2: 41-7.

12. Soniya M, Kuberan T, Anitha S, Sankareswari P. In vitro antibacterial activity of plant extracts against Gram positive and Gram negative pathogenic bacteria. Int J Microbiol Immunol Res. 2013; 2: 1-5.

13. Lateef A, Akande MA, Ojo SA, Folarin BI, GueguimKana EB, Beukes LS. Paper wasp nest-mediated biosynthesis of silver nanoparticles for antimicrobial, catalytic, anticoagulant, and thrombolytic applications. 3 Biotech. 2016; 6: 1-10.

14. Tadesse E, Engidawork E, Nedi T, Mengistu G. Evaluation of the anti-diarrheal activity of the aqueous stem extract of Lantana camara Linn (Verbenaceae) in mice. BMC Complement Altern Med. BMC Complementary and Alternative Medicine; 2017; 17: 1-8.
15. Dubey D, Padhy RN. Antibacterial activity of Lantana camara Linn against multidrug resistant pathogens from ICU patients of a teaching hospital. J Herb Med. 2012; 3: 65-75. Available from: http://dx.doi.org/10.1016/ j.hermed.2012.12.002

16. Minatel IO, Borges CV, Ferreira MI, Gomez HAG, Chen CO, Lima GPP. Phenolic Compounds: Functional Properties, Impact of Processing and Bioavailability. In: SotoHernandez M, Palma-Tenango M, Garcia-Mateos MDR, editors. Phenolic Compd - Biol Act 2017. p. 1-25. Available from: https://www.intechopen.com/books/advancedbiometric-technologies/liveness-detection-in-biometrics

17. Dai J, Mumper RJ. Plant phenolics: Extraction, analysis and their antioxidant and anticancer properties. Molecules. 2010; 15: 7313-52.

18. Macáková K, Kolečkáŕ V, Cahlíková L, Chlebek J, Hoštálková A, Kuča K, et al. Tannins and their Influence on Health. In: Atta-ur-Rahman, Choudhary MI, Perry G, editors. Recent Adv Med Chem. Elsevier Inc.; 2014. p. 159-208.

19. Raiola A, Rigano MM, Calafiore R, Frusciante L, Barone A. Enhancing the health-promoting effects of tomato fruit for biofortified food. Mediators Inflamm. 2014; 2014: 116.

20. Kumar S, Pandey AK. Chemistry and biological activities of flavonoids: An overview. Sci World J. 2013; 2013: 116.

21. Singh B, Singh JP, Singh N, Kaur A. Saponins in pulses and their health promoting activities: A review. Food Chem. Elsevier Ltd; 2017. 223: 540-9.

22. Guo N, Tong T, Ren N, Tu Y, Li B. Saponins from seeds of Genus Camellia: Phytochemistry and bioactivity. Phytochemistry. 2018; 149: 42-55.

23. Barreto FS, Sousa EO, Campos AR, Costa JGM, Rodrigues FFG. Antibacterial activity of Lantana camara Linn and Lantana montevidensis brig extracts from Cariri -Cear, Brazil. J Young Pharm. Elsevier Masson SAS; 2010; 2: 42-4. Available from: http:// dx.doi.org/10.4103/0975-1483.62211

24. Tong SYC, Davis JS, Eichenberger E, Holland TL, Fowler VG. Staphylococcus aureus infections: Epidemiology, pathophysiology, clinical manifestations, and management. Clin Microbiol Rev. 2015; 28: 603-61.

25. Lowe C, Willey B, O'Shaughnessy A, Lee W, Lum M, Pike K, et al. Outbreak of extended-spectrum $\beta$-lactamase -producing Klebsiella oxytoca infections associated with contaminated handwashing sinks. Emerg Infect Dis. 2012; 18: 1242-7.

26. Singh LC, Cariappa MP, Kaur M. Klebsiella oxytoca: An emerging pathogen? Med J Armed Forces India. Director 
General, Armed Forces Medical Services; 2016; 72: S59-

61. Available from: http://dx.doi.org/10.1016/ j.mjafi.2016.05.002

27. Wagner VE, Iglewski BH. P. aeruginosa Biofilms in CF Infection. Clin Rev Allergy Immunology. 2008; 35: 12434.

28. Jaroni D. Salmonella: Salmonella typhi. In: Batt CA, Tortorello M Lou, editors. Encycl Food Microbiol Second Ed. Elsevier; 2014. p. 349-52. Available from: http:// dx.doi.org/10.1016/B978-0-12-384730-0.00296-2

29. Allocati N, Masulli M, Alexeyev MF, Di Ilio C. Escherichia coli in Europe: An overview. Int $\mathrm{J}$ Environ Res Public Health. 2013; 10: 6235-54.
30. Stock I. Natural antibiotic susceptibility of Proteus spp., with special reference to $\mathrm{P}$. mirabilis and $\mathrm{P}$. penneri strains. J Chemother. 2003; 15: 12-26.

31. Pinto E, Monteiro C, Maia M, Faria MA, Lopes V, Lameiras $\mathrm{C}$, et al. Aspergillus species and antifungals susceptibility in clinical setting in the north of Portugal: Cryptic species and emerging azoles resistance in A. fumigatus. Front Microbiol. 2018; 9: 1-9.

32. Kagot V, Okoth S, De Boevre M, De Saeger S. Biocontrol of Aspergillus and Fusarium mycotoxins in Africa: Benefits and limitations. Toxins (Basel). 2019; 11: 1-9. 